\title{
Eco Camp Educational Tourism in The Cybernetics Era: A Study of Ethnostorytelling Through Bumi Langit Permaculture Instagram Account Imogiri, Bantul, Yogyakarta, Indonesia.
}

\author{
Susanti Agustina \\ \{susanti@upi.edu\} \\ Library and Information Science Study Program, Department of Curriculum and Educational \\ Technology, Faculty of Science Education, Indonesia University of Education, Indonesia.
}

\begin{abstract}
This study is aimed to describe the role of folktale as indigenous knowledge that are communicated from generation to generation from the older to the younger in building eco literacy system based on local wisdom. The subject of the study is the Permaculture Community of Bumi Langit Institute and the object of the study is Cybernetics Based-Information Patterns on Instagram. This study used a qualitative method with case study approach. Data were collected through interview, observation and document study. Permaculture Design which is believed to be a holistic approach to life, in fact can be an effective marketing content in the cybernetics era. The marketing of Permaculture Design that is packed using Instagram-ethnostorytelling is an interesting part from the study's findings. Bumi Langit in daily lives as a story can boost the sales of courses and increase farmers'revenue that affects not only the preservation of local wisdom but also sustainable development education and economic development.
\end{abstract}

Keywords: bumi langit, cybernetics, economic literacy, ethnostorytelling, permaculture, sustainable development education.

\section{Introduction}

In the preliminary stages of the project, formulation of the problem came from a brief conversation in Social Media. The member of Whats app group was repost the video of Bumi Langit Institute, the place where ethical values becomes a base foundation inthe relationship between a man and nature. Bumi Langit strive to be a reflection of life that follows (Rahmatan lil a'lamiin). Once in the afternoon (Thrusday, 16 March 2017), researcher arrived in J1 Imogiri Mangunan KM 3, Imogiri, Bantul, Yogyakarta. The researcher had a conversation with an owner of Bumi Langit Institute. The researcher asked about the favourite Culinary which has been seen on Instagram: The deliciously healthy multi grain bread and a glass of homemade kefir. In addition, the researcher also asked why permaculture?. The Informan told us that according to the founder of Bumi Langit, Iskandar Waworuntu whom embraced Islam in 2000 and moved to Jogjakarta to start Bumi Langit in Imogiri by the end of 2006. Bumi Langit strive to be a reflection of life that follows, and Permaculture is a holistic approach to life. After the conversation, the researcher was interested to big deeper into the belief of the Bumi Langit community on the commodity that became its trademark, the Permaculture Design: about the relevance of the activities, the linkages between past stories and beliefs that is formed in the present, and a story of ancestors, in a sustainable development education and economic system as a livelihood. All of it was interesting to be studied further. The 
uniqueness of Bumi Langit local story that is handed down generationally needs to be investigated as an intangible cultural heritage which post on Instagram.

\section{Methodology}

This research employed qualitative method with a case study. Ethnosystem approach, has been used successfully in several socioeconomic and cultural research project and it is continually being adapted and improved,[1]. Ethnostorytelling is composed of two wodes, namely ethno which menas "race, culture," from the Greek ethnos "people, caste, class, ethnicity, nation; a number of people who are used to living together". It is used to form compounds in the modern social sciences. While storytelling refers to the folktales, story, narrative, myte, legend, both oral and written. Both words combined means storytelling culture, by examining the relationship between the tale as a speech language and the culture that envelopes it. it is a combination of Ethnology and storytelling. The study refers to the life of the community where a story develops. All the characteristics of speech language, folktales, stories, legends, myths distinguishe one community from another. These characteristics make the aspects of culture and society. In ethnostorytelling, challenges occur when collecting diverse versions of the presented story, although they lead to the same purpose. The difference between the stories presented orally and in writing facilitates the building of meaning of information between researchers, participants, and key informants. Stories can be a tool to deliver information from the narrative. Stories can help researchers and others to explore and interpret the world and and place where the local people live. Stories are considered as a generative tool to co-design that is capable of recording the self-expression [2]. Thus, stories are useful to draw interest in someone on something. Stories make something unique.

In the cyber era, information can be obtained in a comprehensive system. To obtain something that is needed, individuals will use the Internet in a solution. The Internet has been the most intensive information system in use today. The researchers then searched the Bumi Langit story on the Instagram. This is to observe the response of the story of Bumi Langit Permaculture Design in the virtual world. Apparently, online search results show the unique facts about Bumi Langit stories, "Permaculture Design" (Stories of Daily lives Bumi Langit Community) in generation 2.0, where they build a community of "Permaculture Design" business by using local wisdom in the form of a story in marketing the Courses, either raw or diverse derivative products. This makes the sales situation of permaculture design in the virtual world more creative. How is the role of stories as local knowledge of Bumi Langit community in empowering and contributing to sustainable development education and also economic? This study began building a synthesis of the personal stories of participants/key informants to be a platform for further discussion and analysis of the marketing of Eco Camp Educational Tourism in the era of cybernetics through Instagram. This paper discusses it based on case studies on Instagram interaction.

\section{Result and Discussion}

The Role of Story as Indegenous Knowledge. In the online search about Bumi Langit, the researchers discover a unique writing that packs the story of Bumi Langit daily lives creatively. Stories The story hypnotizes the readers, so they were unaware that the presentation of the story is aimed for marketing, promotion, and advertising. In a story, a 
person can easily absorb knowledge and be affected. The resulting influence of a story can be motivation, inspiration, fantasy, desire, even a feeling of rejection, resistance, or "closing" (purchase) in the context of commerce. The Administator Instagram Account of Bumi Langit, even present a story with contradictory title. If the conventional marketing direct sellers offering wares, then in the second generation cybernetic era, everything changed. Individuals may naively using elements perceived "negative" impact but "positive". Conventional marketing generally offer promise, positive things in the beginning. While in cybernetics this era of marketing has knowledge of the mission. Consumers gain knowledge of the products and services offered based on those values. This is based on the context he wanted to appear as a "trigger" that people are interested in buying a product.

Cybernetics-Based Information Pattern. Cybernetics can help in understanding how knowledge it self is generated. Cybernetics as a controlled system, has a predetermined purpose. Meanwhile, cybernetics as autonomous system lead to systems that define their own purpose [3]. Local stories combined with scientific knowledge is aimed to pack marketing that has a value. The following is a pattern that can be learned from the container (Instagram), content, context that belongs to Administrator in marketing Eco Camp Educational Tourism.[4]-[5].

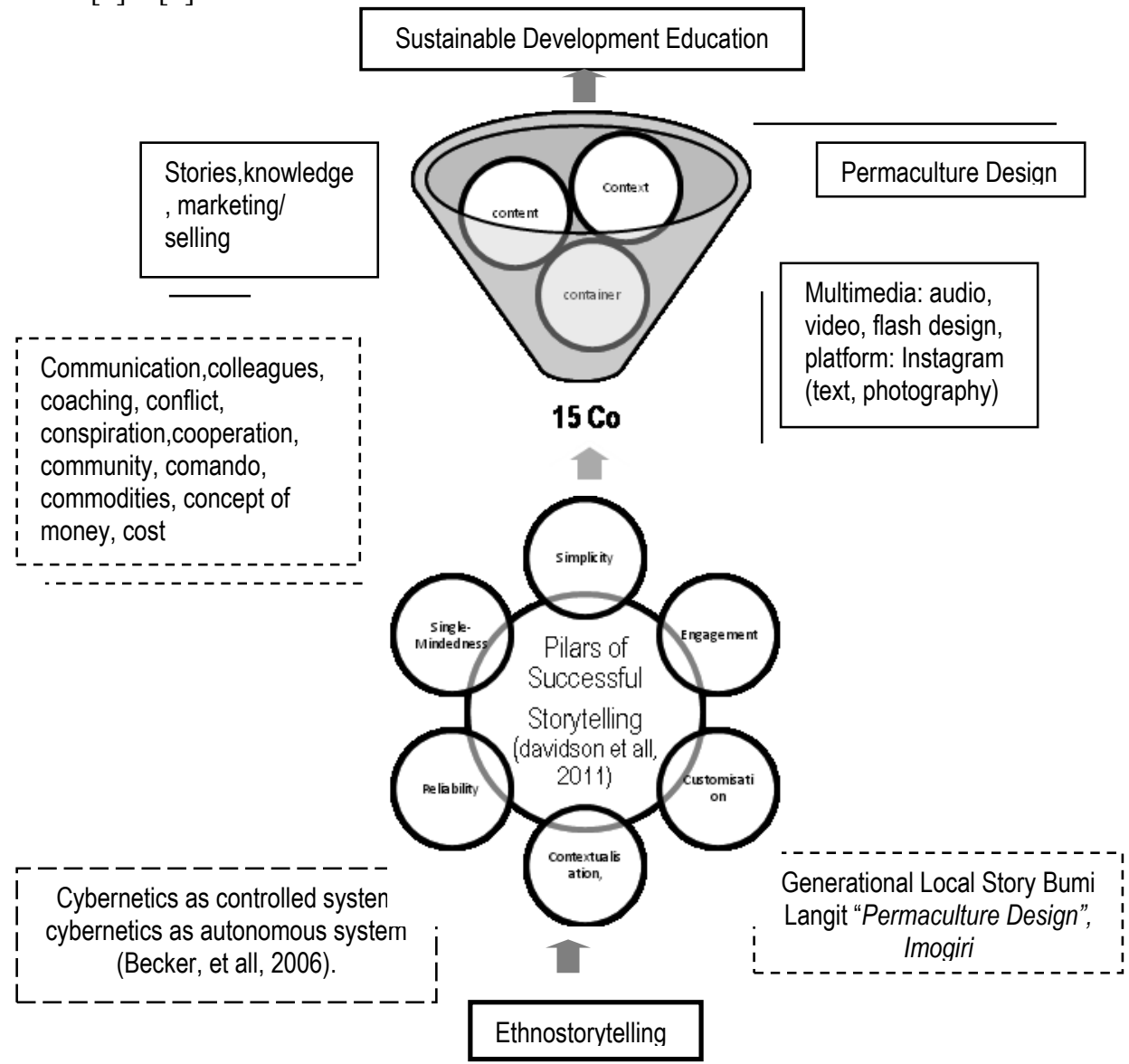

Figure 1. Model of Eco Camp Educational Tourism in The Cybernetics Era Using Instagram Folktale Content 
Table 1. Cybernetics-Based Information Pattern (June, 2013; 01:38 WIB)

\begin{tabular}{|c|c|c|c|}
\hline Category & Percentage (\%) & Liking & Information Pattern \\
\hline Quotes (Q) (f) 7 & $3.8 \%$ & $13.8 \%$ & $\begin{array}{l}\text { Sustainable living, } \\
\text { gardening } \\
\text {,grow your own vegetables, } \\
\text { the happy muslim, little } \\
\text { reminder }\end{array}$ \\
\hline $\begin{array}{l}\text { Local Story (S) } \\
\text { (f) } 156\end{array}$ & $84.8 \%$ & $\begin{array}{l}1740.5 \\
(26.97 \%)\end{array}$ & $\begin{array}{l}\text { The daily activity, what their } \\
\text { produce, the story of their } \\
\text { life }\end{array}$ \\
\hline $\begin{array}{l}\text { Scientific } \\
\text { Knowledge (K) } \\
\text { (f) } 13\end{array}$ & $7.065 \%$ & $\begin{array}{l}1488 \\
(24 \%)\end{array}$ & $\begin{array}{l}\text { The description and also } \\
\text { several other beneficial } \\
\text { effect on health of } \\
\text { vegetables and fruits }\end{array}$ \\
\hline $\begin{array}{l}\text { Marketing } \\
\text { (M) } \\
\text { (f) } 8\end{array}$ & $4.35 \%$ & $\begin{array}{l}2482 \\
(38.49 \%)\end{array}$ & $\begin{array}{l}\text { Permaculture Design } \\
\text { Course, Permakids } \\
\text { education courses }\end{array}$ \\
\hline
\end{tabular}

Source: @Bumilangit.official (184 post; 6450 follower; 192 followed) Instagram Account since Nov 16 th 2015-July 18 th 2017.

Based on the table, it can be concluded that the pattern of the information contained in Instagram (as a container) reveals more local story (S), i.e $84.8 \%$. of the total writing content on the context of marketing of Bumi Langit Permaculture Design. Then, the marketing missions (M) has $4.35 \%$ of the total writing content on the context of marketing of Bumi Langit Permaculture Design. While the scientific Knowledge is $7.065 \%$ of the total writing content on the context of marketing of Bumi Langit Permaculture Design. The persentage of Quotes posting in Instagram just $3.8 \%$. The writing pattern in the Intsgram caption, means that the writing of information begins with a prologue $(\mathrm{P})$ in the form of a quote of case examples that becomes the main idea of the information that will be presented. It ends with the question of why. This question at the same time opens the chance to deliver more about the context. After that, in the description under the picture or video, Administrator Instagram Account of Bumi Langit started a story/narrative of Bumi Langit daily lives in the concluded version, no longer tells the original history. assumes that customers already know the story of Bumi Langit, so he did not need to tell it in detail. Interestingly, admint actually does a "trigger" in the title of narrative in their caption. The sentence also reminds the readers on the original Bumi Langit local story. That is the local version of the story that is passed down generationally until the story develops and increasingly believed by the local people. The informaton Age is characterized by information overload and difficulty experienced in making sense of the data [6]

The Administrator of Bumi Langit instagram account modifies the marketing by packing the context of local stories by inserting a scientific reason to boost the sale of Bumi Langit Permacuture Design Courses, without losing the essence of the contents of the local stories. In the Marketing mission, the pattern of the information presented is incorporates story elements as much as 2 developed ideas, while knowledge and marketing elements as much as one idea. 


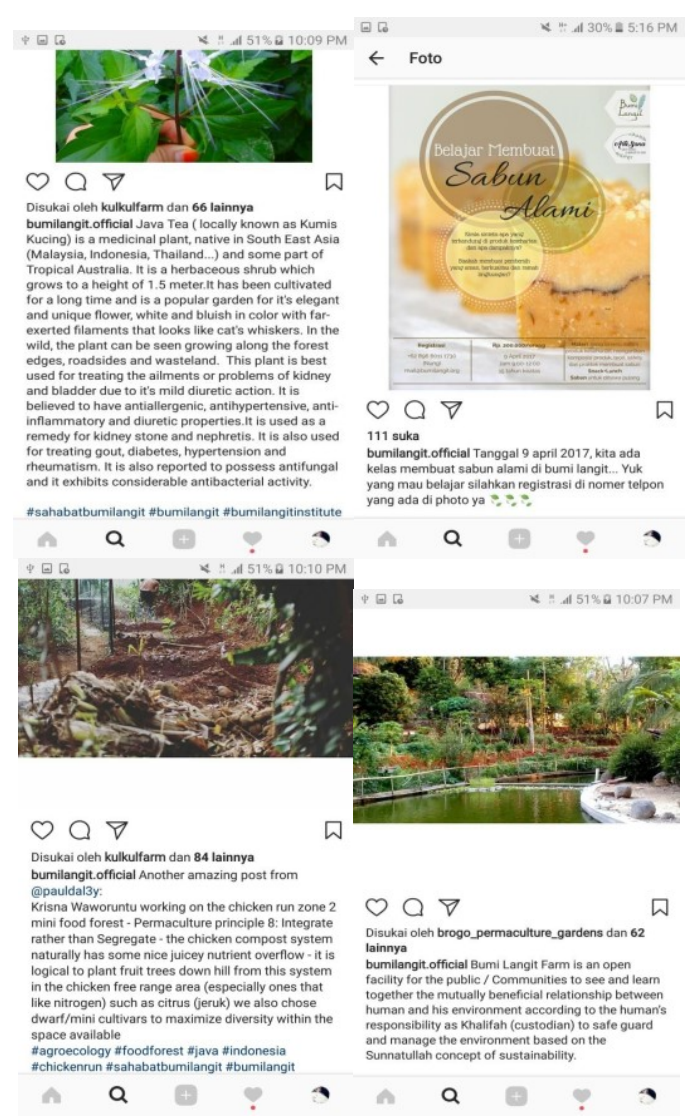

Figure 2. Example Local Story Content of Instagram

It is therefore important for marketing through information clutter when presenting the research result to customers [7]-[8] state that since the beginning of humanity, storytelling already exist. At first, storytelling is used as a process of learning to think critically and understand also drafted a common experience [9]. In this Instagrambased cybernetic era, Administator do ethnostorytelling by utilizing information technology. The role that technology has played in the history of storytelling: in the past, technology was used as a tool to spread stories to a wider audience; precently, it used as a tool that is an integrated part of the storytelling process and of the story itself [10]. Daily story about the Bumi Langit Institute and then meet with nature knowledge that proves that the Permaculture Design is a holistic approach to life. The scientific explanation also strengthen the notion that the local people's thinking technology in ancient times have made progress in terms of container and content. With answers using scientific knowledge, the context is more convincing to customers as instagram followers that there is a process which makes the relationship between man and nature. The Administrator seize these opportunities as a form of creative thinking. About the need for variation, the idea to coordinate themselves produce a basic draft. To change an object of local stories where there is interaction 
between the object and its environment will alter the object as desired [11]. The administrator shows a good behavior of information seeking, which is referring to the sources of primary information by reading documentary evidence such as quote photographs. Storytelling is used in many different business diciplines, some of the which are leadership, management, coaching, selling, education, and branding. [12] [13] - [14] . Information pattern in the Bumi Langit Instagram account raises two developed ideas of the quotes- knowledge element. [15] add that storytelling facilitates knowledge sharing, guides decision-making and creates commitment to change.

The information pattern of the Bumi Langit Instagram account is marketing with e-flyer. In these photograph, the story element does not exist. They still emphasize the elements of knowledge that explains the facts of the story and also element of marketing that uses the story as a scientific reason, rational and practical study. This broke the presumption that a story is the antithesis of scientific, objective or rational research practice.[16]-[17], that the use of stories lacks perception. Storytelling offers various advantages. It facilitates enganging and interactive conversations, is intuitive, stimulaes the brain and aids recall, is simplified, increases impact and facilitates understanding [18]-[19]-[20]-[21]—[22] - [23].The application of the model 15-Co for product marketing can be developed in other contexts, such as products and services that elevates local knowledge for sustainable development education [24]-[25] - economic of community.

1. Facilitation of training and workshops for SMEs in building cybernetics ethnostorytelling for local products are needed.

2. The mapping of information content in the form of a narrative that uses social media especially Instagram is needed.

\section{Conclusion}

a. A story is a narrative information that in the era of modern cybernetics no longer a container and contents but also lead to the context.

b. A local story can become the people's choice in strengthening the resilience of the economy in various fields.

c. A local story can be an affirmation that educate, so that local people have the ecoeconomic literacy skills.

d. Eco literacy is simply interpreted as "reading to obtain financial gain," at least microfinancial.

e. Etnostorytelling marketing for the distribution of Permaculture design daily story is packaged using the principles of $15 \mathrm{C}$ and 6 pillars of successful storytelling.

f. Cybernetics model as a controlled system and cybernetics as an autonomous system both apply to ethnostorytelling marketing via multimedia [26] (video \& photograph, text in Instagram)

g. The most fundamental behavioral changes are the growth of interest in the 
environment and all things related to nature conservation, to get used to live a healthy, efficient, and useful life.

\section{References}

[1] Slikkerveer, L.J, The Rise of Ethnomedicine in Indonesia: Innovative Wisdom for The Advancement of the medical Social Dciences. Bandung: Unpad., 2005.

[2] Saunders E.B.N, Generative Tools for CoDesign Retrieved from http://www.daimi.au.dk/ pkrogh/UX_kursus_aaaE09/Sanders\%20generative\%20tools.pdf, 2000.

[3] Becker, et all., The History and Development of Cybernetics. The George Washington University, 2006.

[4] S. Agustina and W. Erwina, Marketing of Cilembu Sweet Potato Seeds in The Cybernetics Era Through The Content of Dongeng Hui Cilembu: A Study Ethnostorytelling at Cilembu Village, Sumedang, West Java, Indonesia, ICIMM Proceeding Published by Atlantis Press, Thomson Reuters indexing, 2016.

[5] S. Agustina, Eco Camp Educational Tourism Phenomenon in Indonesia. JSDER Vol.1 No 1, pp.4554, 2017.

[6] Doyle, A and Tharme, A. Do researchers understandvisual design?, viewed 12 August 2016, from http://www.research-live.com/features/do- researchers-understandvisualdesign?/4004766.article. ,2011.

[7] Doyle, A and Tharme, A. Do researchers understandvisual design?, viewed 12 August 2016, from $\mathrm{http}: / /$ www.research-live.com/features/do-researchers-understandvisualdesign?/4004766.article.,2011.

[8] Tobin, P.K.J. \& Snyman, R., Once upon a time in Africa: A cas study of storytelling for knowledge sharing. Aslib Proceedings 60 (2). Pages.130-142. http://dx.doi.org/10.1108/00012530810, 2008

[9] Carter-Black, Teaching Cultural Competence: An Innovative Strategy ground, page 32, 2007.

[10] Czarnecki, K., storytelling in context. In digital storytelling in practice, Library Technology Reports, Chicago, IL. Pages 1-5, 2009.

[11] Becker, et all.,The History and Development of Cybernetics. The George Washington University, 2006.

[12] Bosworth, M. \& Zoldan,B, 2012, What great salespeople do: The Science of selling through emotional connection and the power of story, Mc GrawHill Companies, Inc. Hoboken, NJ.

[13] Carr, A.N. \& Ann,C., 2011, The use and abuse of storytelling in organizations', journal of Management Development 30 (3), pages 236-245, 2011.

[14] Silverman, LL., 2006, Wake me up when the data is over, John Wiley \& Sons, Inc., Hoboken, NJ.

[15] James, C. and Minnis, W.c., Organizational storytelling: it makes sense', business horizons 47 (4), Pages 23-30. http://dx.doi.org/10.1016/S0007-6813 (04)00045- X, 2004.

[16] Florence, C, A matter od fact, not fiction, viewed February 2015,from.http://www.researchlive.com/comment/a-matter-of-fact-not- fiction/4009220.article.2013

[17] Ghoshal, N.D., 2011, Storytelling:Co-create atale', admap, October, page.4.

[18] Carr, A.N. \& Ann,C., 2011, The use and abuse of storytelling in organizations', journal of Management Development 30 (3), pages 236-245, 2011.

[19] Davison, L., As stimulating as black coffee- communications that are hard to sleep after, paper presented at ESOMAR Annual Congress, Amsterdam, The Netherlands, September. pages. 12- 16, 2011.

[20] Few, S., The chartjunk debate. A close examination of recent findings', Visual Business Intelligence Newsletter April/May/June.Available from $\mathrm{http} / / /$ www.perceptualedge.com/articles/visual_busin ess_intelligence/the_chartjunk_debate.pdf. page.10, 2011.

[21] Kaidi, Z., Data Visualization, viewed 12 August 2012, from http://www.cs.uic.edu/ $/$ kzhao/papers/00_course_Data visualization.pdf, 2012.

[22] Maritz, V., Petzer, D.J. \& De Meyer, C., The use of storytelling in quantitative research reports: A 
marketing research firm perspective, Acta Commercii 14 (2), Art. \#48, 10 pages. http://dx.doi.org/10.4102/ac.v14i2.248, 2014.

[23] Ethnojournalism.org, 2016, Multimedia Empowerment \& storytelling. Hosted by ibiblio.org.

[24] Ali, M., Education for national development: A case study of Indonesia (Second edition). Bandung: Imperial Bhakti Utama, 2014a.

[25] Ali, M., Sustainable development: Role of education. Proceeding of International Conference on Education for Sustainable Regional Development.Joinly organized by Universitas Pendidikan Indonesia and University Kebangsan Malaysia, on October 31st - November 2nd, in Bandung, Indonesia, 2016

[26] Deloitte, Tech Trends 2011 (electronic Version), viewed April 2016, from http://www.deloitte.com/us/2011 techtrends\#download, 2011. 